\title{
The first record of Perregrinus deformis (Tanasevitch, 1982) from Fennoscandia (Aranei: Linyphiidae)
}

\author{
Первая находка Perregrinus deformis (Tanasevitch, 1982) \\ в Фенноскандии (Aranei: Linyphiidae)
}

\author{
Anna A. Nekhaeva \\ А.A. Нехаева \\ Severtsov Institute of Ecology and Evolution, Russian Academy of Sciences, Leninsky pr. 33, Moscow, 119071, Russia. E-mail: \\ Adrealinea@gmail.com \\ Институт проблем экологии и эволюции им. А. Н. Северцова РАН, Ленинский пр. 33, Москва 119071, Россия.
}

KEY WORDS: Spiders, Fennoscandia, new record, Perregrinus deformis.

КЛЮЧЕВЫЕ СЛОВА: Пауки, Фенноскандия, новая находка, Perregrinus deformis.

ABSTRACT. The Siberian-Nearctic linyphiid spider Perregrinus deformis (Tanasevitch, 1982) is recorded from Fennoscandia for the first time. The vicinity of Murmansk is the westernmost locality of species' known distribution in the Palaearctic Region. On the basis of new data, the species displays a Fennoscandian-Siberian-Nearctic range.

РЕЗЮМЕ. Считавшийся ранее сибирско-неарктическим, вид Perregrinus deformis (Tanasevitch, 1982 ) впервые найден в Фенноскандии, в окрестностях Мурманска. На сегодняшний день это самая западная, из известных, точка распространения вида в Палеарктике. Согласно новым данным, ареал вида может быть охарактеризован как Фенноскандинавско-сибирско-неарктический.

\section{Introduction}

Despite the spider fauna of the Kola Peninsula is well-studied and numbers 228 species [Tanasevitch, Kamayev, 2010], new findings are still possible. The linyphiid spider Perregrinus deformis (Tanasevitch, 1982) earlier known from Siberia and the Nearctic Region has been found from the vicinity of Murmansk.

The sampling site $\left(68^{\circ} 54.356^{\prime} \mathrm{N}, 033^{\circ} 01.194^{\prime} \mathrm{E}\right)$ is situated on the West coast of Kolskiy Gulf (Fig. 1), near the road Murmansk - Pechenga. The studied area is under anthropogenic impact and differs from the adjacent forests in reduced plant diversity. Its plant community consists of young Betula stands (hight 0,5 $1,0 \mathrm{~m})$ with Vaccinium myrtillus, $V$. vitis-idaea, $V$. uliginosum, Empetrum sp., Calluna vulgaris and Ledum palustre, the litter is mostly absent, moss and lichens are scarcely available.

The studied material was collected by pitfall traps (with 4\% formaldehyde) during the period of 16-23 May 2010. All the measurements were made by using
MBS-9 stereomicroscope with eyepiece-micrometer and given in $\mathrm{mm}$. The material is deposited in the Zoological Museum of the Moscow State University, Russia.

\section{Results}

An adult female of $P$. deformis was collected (Fig. 2A): its total length 1.6; carapace 0.8 long, 0.6 wide, pale grey; abdomen 0.9 long, 0.6 wide, dark grey. Legs yellowish. The epigyne is typical for the species, as shown in Fig. 2B.

$P$. deformis was originally described from the Polar Urals [Tanasevitch, 1982]. Later on it was recorded from Siberia [Mikhailov, 1997; Marusik et al., 2000; Tanasevitch, 2007; Marusik \& Eskov, 2009], Mongolia and China [Eskov, 1994; Song et al., 1999], and from Canada [Koponen, 1994; Dondale et al, 1997; Paquin et al., 2010]. To date, the westernmost locality of the species' distribution has been Indiga situated in the Malozemelskaya tundra, Arkhangelsk Area [Tanasevitch \& Koponen, 2007].

As $P$. deformis have never earlier been found in well-studied Fennoscandia, it is safe to assume that species is either quite rare there or was confused with another species. On the basis of the new data, the species displays a Fennoscandian-Siberian-Nearctic range.

ACKNOWLEDGEMENTS. I am very grateful to Dr Andrei Tanasevitch, Centre for Forest Ecology and Production RAS, Moscow, Russia, for his extensive help in the preparation of this paper. Special thanks go to Ivan Nekhaev, Murmansk Marine Biological Institute KSC RAS, Murmansk, Russia, for correcting the English and critical remarks on an earlier draft. The study was supported by the President Program for the Support of Leading Scientific Schools (3807.2012.4) and the Russian Foundation for Basic Research (RFFI), grant \# 11-04-017725-a. 


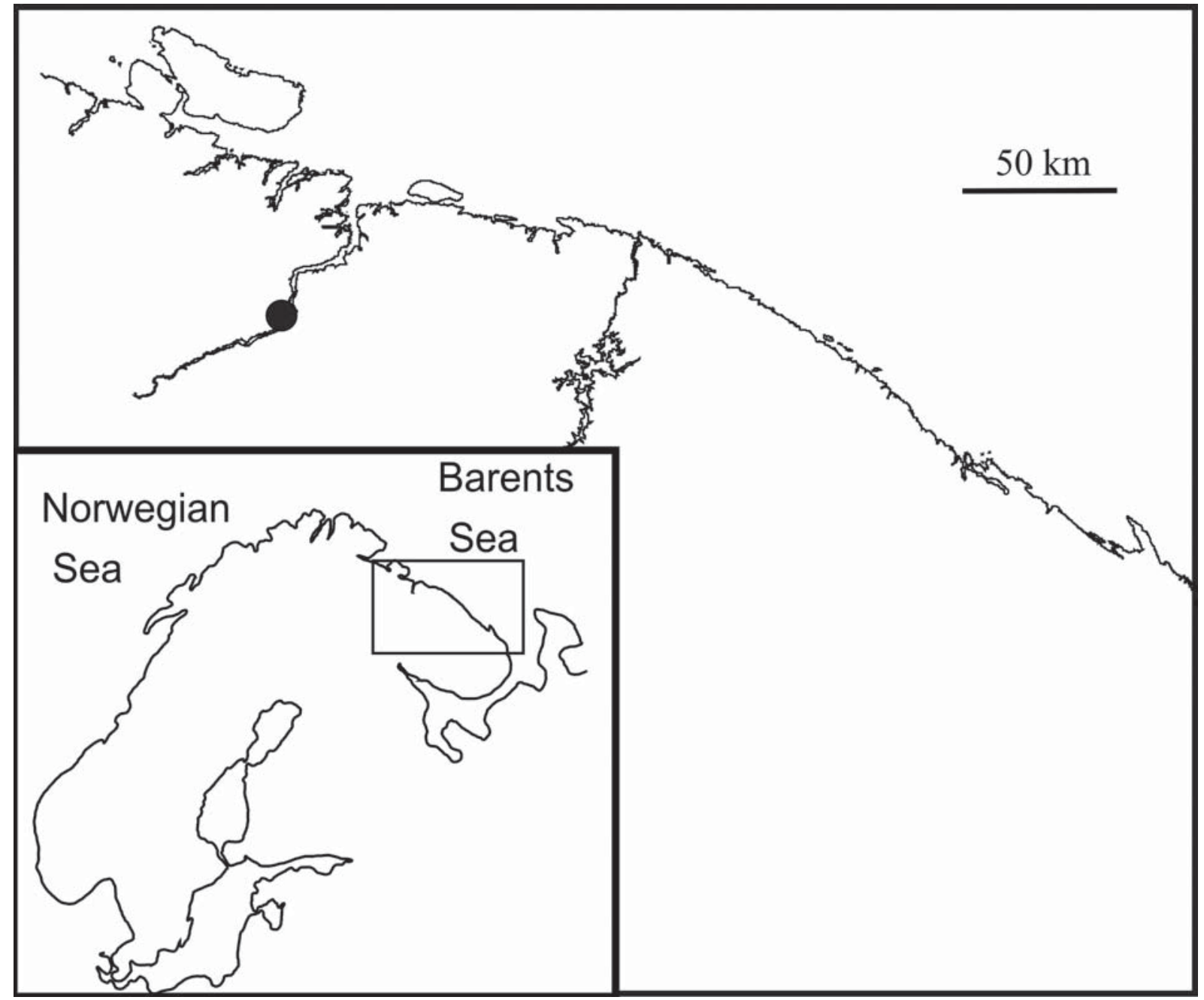

Fig. 1. Locality of Perregrinus deformis (Tanasevitch, 1982) in Kola Peninsula.

Рис. 1. Местонахождение Perregrinus deformis (Tanasevitch, 1982) на Кольском п-ове.

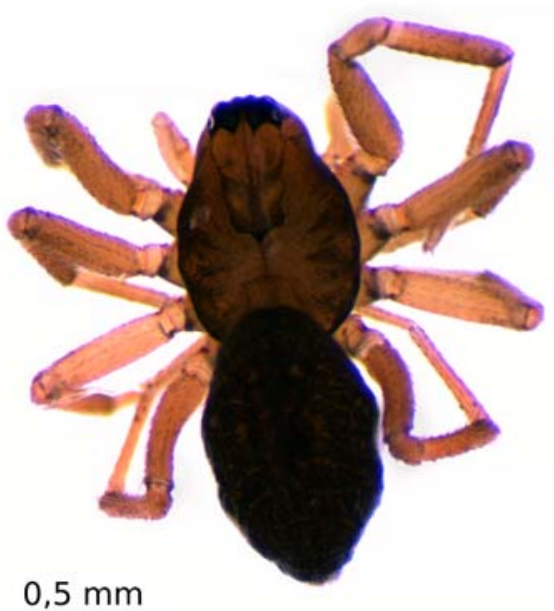

A

Fig. 2. Perregrinus deformis (Tanasevitch, 1982), ㅇ: a - habitus, scale bar $=0.5 \mathrm{~mm}$; b - epigyne, scale bar $=0.1 \mathrm{~mm}$.

Рис. 2. Perregrinus deformis (Tanasevitch, 1982), ㅇ: a — внешний вид, масштаб 0,5 мм; b — эпигина, масштаб 0,1 мм. 


\section{References}

Dondale C.D., Redner J.H., Marusik Y.M. 1997. Spiders (Araneae) of the Yukon // Danks H.V. \& Downes J.A. (eds.). Insects of the Yukon. Biological Survey of Canada (Terrestrial Arthropods), Ottawa. P. 73-113.

Eskov K.Yu. 1994. Catalogue of the linyphiid spiders of Northern Asia (Arachnida, Araneae, Linyphiidae). Sofia-Moscow: PENSOFT Publ. $144 \mathrm{p}$

Koponen S. 1994. Ground-living spiders, opilionids, and pseudoscorpions of peatlands in Quebec // Mem. Entomol. Soc. Canada. Vol.169. P.41-60.

Marusik Yu.M., Eskov K.Y. 2009. [Spiders (Arachnida: Aranei) of the tundra zone of Russia] // Vidy i soobshchestva v ekstremal'nykh usloviyakh. Moscow - Sofia: KMK - PENSOFT Publ. P.92-123 [in Russian, with English summary].

Marusik Yu.M., Logunov D.V., Koponen S. 2000. Spiders of Tuva, South Siberia. Magadan: IBPN FEB RAS. 252 p.

Mikhailov K.G. 1997. Catalogue of the spiders of the territories of the former Soviet Union (Arachnida, Aranei). Moscow: Zoological Musuem of the Moscow State University. 416 p.
Paquin P., Buckle D.J., Depérré N., Dondale C.D. 2010. Checklists of the spiders (Araneae) of Canada and Alaska // Zootaxa. Vol.2461. P.1-170.

Song D., Zhu M.S., Chen J. 1999. The Spiders of China. Shijiazhuang: Hebei Sci. Technol. Publ. House. 640 p.

Tanasevitch A.V. 1982. [A new genus and new species of spiders of the family Linyphiidae (Aranei) from the Bolshezemelskaya Yundra] // Zool. Zhurnal. Vol.61. No.10. P.1501-1508 [in Russian, with English summary].

Tanasevitch A.V. 2007. New records of linyphiid spiders from Russia, with taxonomic and nomenclatural notes (Aranei: Linyphiidae) // Arthropoda Selecta. Vol.16. No.2. P.115-135.

Tanasevitch A.V., Kamayev I.O. 2011. [Spiders of the Kola Peninsula, Russia (Arachnida: Aranei)] // Caucasian Entomological Bull. Vol.7. No. 1. P.7-32 [in Russian, with English summary].

Tanasevitch A.V., Koponen S. 2007. Spiders (Aranei) of the southern tundra in the Russian Plane // Arthropoda Selecta. Vol.15 (for 2006). No.4. P.295-345.

Responsible editor D.V. Logunov 